\title{
Protein synthesis in gilthead sea bream: response to partial fishmeal replacement
}

\author{
Chris G. Carter $^{1 *}$, Elena Mente ${ }^{2,3}$, Robin (Katersky) Barnes ${ }^{4}$ and Ioannis Nengas ${ }^{5}$ \\ ${ }^{1}$ Institute for Marine and Antarctic Studies, University of Tasmania, Private Bag 49, Hobart, Tasmania 7001, Australia \\ ${ }^{2}$ Department of Ichthyology and Aquatic Environment, School of Agricultural Sciences, University of Thessaly, Fytoko Street, \\ Nea Ionia, Magnisia, Greece \\ ${ }^{3}$ Institute of Biological and Environmental Sciences, School of Biological Sciences, University of Aberdeen, Tillydrone \\ Avenue, Aberdeen AB24 2TZ, UK \\ ${ }^{4}$ National Centre for Marine Conservation and Resource Sustainability, University of Tasmania, Locked Bag 1370, \\ Launceston, Tasmania 7250, Australia \\ ${ }^{5}$ Hellenic Centre for Marine Research, Institute of Aquaculture, Elliniko 16610, Agios Kosmas, Athens, Greece
}

(Submitted 13 October 2011 - Final revision received 5 January 2012 - Accepted 24 January 2012 - First published online 14 March 2012)

\begin{abstract}
The present study aimed to measure tissue protein synthesis in sea bream fed isonitrogenous diets that contained 63,55 and $50 \%$ fishmeal; in the latter two diets, 16 and $27 \%$ of the fishmeal protein was replaced with plant protein. Over a $35 \mathrm{~d}$ period, there were no differences in feed intake, growth or feed efficiency among the three diets. Protein metabolism was then measured in the liver and white muscle tissue as rates of protein synthesis and as the capacity for protein synthesis before feeding $(0 \mathrm{~h})$ and at different times after feeding ( $4-48 \mathrm{~h})$. Diet did not have a significant effect on protein synthesis or on the capacity for protein synthesis in either tissue. The capacity for protein synthesis was not affected by time after feeding, and overall mean values were 81.02 (SE 1.68) and 4.07 (SE 0.94) $\mathrm{mg} \mathrm{RNA} / \mathrm{g}$ protein for the liver and white muscle, respectively. Liver and white muscle fractional rates of protein synthesis were significantly higher at $4-8 \mathrm{~h}$, intermediate at $12 \mathrm{~h}$ and were not different among pre-feeding $(0 \mathrm{~h}), 24$ and $48 \mathrm{~h}$. Overall, the indices of protein metabolism measured at various times over $48 \mathrm{~h}$ following feeding were closely aligned with measurements of feeding, growth and growth efficiency established over a longer time scale.
\end{abstract}

Key words: Protein synthesis: Specific dynamic action: Fishmeal replacement

The development of sustainable aquaculture is partly dependent on sustainable aquafeeds and the replacement of some or all of the protein and oil derived from marine sources ${ }^{(1-3)}$. Strategies include the use of protein and oil sources derived from agriculture production as well as consideration of organic and certified ingredients that may include those of marine origin $^{(4,5)}$. While considerable knowledge exists about the use of alternative protein sources in aquafeeds, the majority of this has been obtained from long-term growth experiments. Protein turnover is clearly of central importance to growth but only a few studies on fish have investigated protein turnover ${ }^{(6)}$, protein synthesis and protein degradation, in relation to dietary modification; even fewer have investigated the effect of replacing fishmeal on protein synthesis ${ }^{(7-10)}$. Protein turnover reflects dietary protein in relation to how closely it matches quantitative and qualitative amino acid requirements ${ }^{(11-13)}$. Low or imbalanced amino acid supply tends to initially stimulate protein synthesis in the liver in order to maintain protein synthesis and growth in the skeletal muscle ${ }^{(9)}$. Prolonged feeding at a low intake of amino acids will down-regulate protein synthesis so that liver rates decrease to be the same or lower than on a higher-quality protein source and skeletal muscle protein synthesis cannot be sustained and will be depressed $^{(11,14)}$. When an alternative dietary protein is of high quality, muscle protein synthesis may not be affected by protein sources used, as in barramundi (Lates calcarifer) fed lupin meal to replace $45 \%$ of the fishmeal protein ${ }^{(15)}$. In contrast, wholeanimal protein synthesis differed between rainbow trout (Oncorbynchus mykiss) fed two isonitrogenous diets but with varying amounts of fishmeal and other protein sources ${ }^{(16)}$.

Abbreviations: FM63, 63\% fishmeal; FM55, $55 \%$ fishmeal with approximately 16\% fishmeal protein replaced by soyabean protein; FM50, 50 \% fishmeal with approximately $27 \%$ fishmeal protein replaced by soyabean and maize gluten protein; W, wet weight.

*Corresponding author: Professor C. G. Carter, fax +61 362278035, email chris.carter@utas.edu.au 
Postprandial changes in protein synthesis determine a large proportion of specific dynamic action ${ }^{(17,18)}$ and are influenced by nutritional factors including feed intake and diet composition. Peak rates of protein synthesis generally occur between 4 and $12 \mathrm{~h}$ after a meal and measurement of protein synthesis has been proposed as a potentially sensitive method to compare diets and explain some nutritional effects ${ }^{(11,19)}$. Very few studies have compared the combined effects of diet and time after feeding on fish protein synthesis in vivo. In the aforementioned study on barramundi fed the lupin meal ${ }^{(15)}$, protein synthesis was not affected by protein source at peak ( $4 \mathrm{~h}$ ) or at basal $(24 \mathrm{~h})$ rates. It was therefore of interest to further investigate the effect of alternate protein sources on protein synthesis in the present study on gilthead sea bream (Sparus aurata L.) and at greater resolution than in any previous research on fish by considering multiple times following feeding. This is relevant in that plant proteins are likely to alter tissue free amino acid pools ${ }^{(20)}$ and the time of peak postprandial digestive enzyme activity $^{(21)}$ in sea bream. Several potential alternate proteins have been successfully tested with sea bream and inclusion of $30 \%$ of soyabean did not significantly affect growth, feed or protein efficiency ${ }^{(22-24)}$ and was selected as the primary not significantly affect growth, feed or protein efficiency alternative to fishmeal in the present study.

The principal aim of the present study was to assess postprandial protein synthesis as a sensitive test of nutritionally similar diets with different ingredient composition. Measurement of protein synthesis using a flooding dose of a labelled amino $\operatorname{acid}^{(25)}$ has advanced the understanding of the relationships between diet composition, protein metabolism and nutrient utilisation in aquatic animals and is the method that has been used most extensively in fish ${ }^{(8,9,26)}$. However, the complexity of the method means that there are relatively few published studies on fish that compare diets ${ }^{(11,27)}$. Consequently, new research adds considerably to the existing pool of information. Protein metabolism was measured before feeding and at five times after feeding over a period of $48 \mathrm{~h}$ in order to make a detailed comparison of partial fishmeal replacement with soyabean. A third diet was then used to assess whether measuring protein synthesis at three critical times provided sufficient resolution of postprandial changes in order to validate the optimum measurements.

\section{Methods \\ Experimental diets}

In the present study, three isonitrogenous diets were formulated to compare the effect of partial fishmeal replacement (Table 1): one used a sustainable certified Peruvian fishmeal (FM63); the second used soyabean protein to replace approximately $16 \%$ of the fishmeal protein (FM55); and the third used soyabean and maize gluten protein to replace approximately $27 \%$ of the fishmeal protein (FM50). Ingredients were sourced from the Zoonomi Aquafeed Company. Diets were prepared at the Fish Nutrition and Pathology Laboratory, Institute of Aquaculture, Hellenic Centre for Marine Research.
Table 1. Ingredient and chemical composition of the three partial fishmeal replacement experimental diets (FM63, FM55 and FM50)

\begin{tabular}{lccc}
\hline & \multicolumn{3}{c}{ Diets } \\
\cline { 2 - 4 } & FM63 & FM55 & FM50 \\
\hline Ingredient composition (g/kg) & & & \\
$\quad$ Fishmeal & 630 & 550 & 500 \\
Soyabean meal & & 100 & 160 \\
Maize gluten & & & 75 \\
Fish oil & 90 & 90 & 140 \\
Wheat & 265 & 252 & 117 \\
Choline & & 3 & 3 \\
Vitamin and mineral premix & 5 & 5 & 5 \\
Chemical composition (g/kg DM) & & & \\
DM (g/kg) & 900 & 920 & 910 \\
Crude protein & 450 & 450 & 460 \\
Total lipid & 140 & 140 & 180 \\
Crude fibre & 6 & 10 & 17 \\
Ash & 110 & 68 & 98 \\
CHO* & 300 & 342 & 262 \\
GE (kJ/kg DM) $\dagger$ & $21 \cdot 3$ & $22 \cdot 0$ & 22.5 \\
\hline
\end{tabular}

$\mathrm{CHO}$, carbohydrate; GE, gross energy.

${ }^{*} \mathrm{CHO}$ calculated by difference $(100 \%-$ (crude protein $(\%)+$ total lipid $(\%)+$ ash $(\%)$ ).

† GE calculated from nutrients assuming a GE content of $23.6 \mathrm{~kJ} / \mathrm{g}$ for protein $39.5 \mathrm{~kJ} / \mathrm{g}$ for lipid and $17.2 \mathrm{~kJ} / \mathrm{g}$ for carbohydrate ${ }^{(46)}$.

\section{Growth experiment}

Gilthead sea bream were obtained from a commercial fish farm (SE Saronic Gulf) and reared at the Fish Nutrition and Pathology Laboratory, Institute of Aquaculture (Hellenic Centre for Marine Research). Care and use of animals was according to the institutional procedures at the Hellenic Centre for Marine Research. Fish were held in $2 \mathrm{~m}^{3}$ experimental net cages $(1 \mathrm{~m} \times 2 \mathrm{~m} \times 1 \mathrm{~m}$ deep) suspended in a concrete raceway supplied continuously with filtered seawater; there were three cages per treatment and these were each stocked with twenty fish. Fish were fed ad libitum by hand three times daily at 09.00 , 12.00 and 15.00 hours for $35 \mathrm{~d}$ to measure feed intake and growth. At the end of this period, fish were used to measure liver and white muscle protein synthesis before feeding and at up to five times after feeding (see below). Fish were killed by anaesthesia (diluted 1:1 phenoxyethanol in ethanol) and a blow to the head, wet weight (W) was measured and the tissues rapidly dissected out, samples weighed and frozen in liquid $\mathrm{N}_{2}$. W was measured in all the remaining fish not used for protein synthesis. The hepatic somatic index (HSI; \% weight) was calculated as $\mathrm{HSI}=100 \times($ liver weight/W) where liver weight and $\mathrm{W}$ are in $\mathrm{g}$.

\section{Protein synthesis}

Liver and white muscle rates of protein synthesis were measured following a single flooding dose of $\left[{ }^{3} \mathrm{H}\right]$ phenylalanine ${ }^{(25,28)}$ before feeding, and at 4, 8, 12, 24 and $48 \mathrm{~h}$ after feeding; protein synthesis was not measured at 8 and $12 \mathrm{~h}$ for fish fed FM55. Replicate samples, taken at 28, 55, 71, 110 and $176 \mathrm{~min}$, were used to establish a time course and validate the method. Fish were injected into the caudal vein with $1.0 \mathrm{ml} / 100 \mathrm{~g}$ injection solution. Following injection, fish were returned to tanks in an indoor system 
held under constant environmental conditions and containing aerated seawater; they were removed and killed after a known time. The injection solution contained $150 \mathrm{mmol} \mathrm{L-phenyl-}$ alanine and $\mathrm{L}-\left[2,6-{ }^{3} \mathrm{H}\right]$ phenylalanine (Amersham Pharmacia Biotech) in $0 \cdot 2 \mu \mathrm{m}$ filtered seawater at $\mathrm{pH} 7 \cdot 4$ with a measured specific activity of 1473 (SE 252) dpm/nmol phenylalanine. The treatment of samples to measure protein-bound and free-pool phenylalanine-specific radioactivity was as described previously for fish ${ }^{(28)}$. Fractional rates of protein synthesis $\left(k_{\mathrm{s}}\right.$ : $\% / \mathrm{d})$ were calculated as $k_{\mathrm{s}}=100 \times\left(\left(S_{\mathrm{b}} / S_{\mathrm{a}}\right) \times\left(1440 / t_{1}\right)\right)$, where $S_{\mathrm{b}}$ is the protein-bound phenylalanine-specific radioactivity at time $t_{1}(\mathrm{~min})$ and $S_{\mathrm{a}}$ the free-pool phenylalaninespecific radioactivity $(25,29,30)$. Protein concentration was measured using a modification of the Folin phenol method $^{(31)}$ and RNA concentration was measured using dual-wavelength absorbance ${ }^{(32)}$. RNA was also expressed as the capacity for protein synthesis $\left(C_{\mathrm{s}}: \mathrm{mg} \mathrm{RNA} / \mathrm{g}\right.$ protein) and as RNA activity $\left(k_{\mathrm{RNA}}: k_{\mathrm{s}} / \mathrm{g} \text { RNA per } \mathrm{d}\right)^{(33)}$.

\section{Statistical analysis}

Data are presented as means with their standard errors. Homogeneity was confirmed using Levene's test. One-way ANOVA and linear regression were used to analyse the relationship between incorporation time and both free-pool and proteinbound phenylalanine-specific radioactivity for each tissue ${ }^{(25)}$. Two-way ANOVA was used to analyse the effect of diet and time after feeding on protein synthesis and capacity for protein synthesis. When there was no significant interaction between the two factors, the main effects were analysed. Significance was accepted at $5 \%$ or less. All statistical analyses were carried out using IBM SPSS Statistics, version 19.

\section{Results}

\section{Growth performance}

Diet had no effect on the growth performance of sea bream: there were no significant differences among the diets for final weight, weight gain, specific growth rate, feed intake and feed efficiency ratio (Table 2). Liver weight was significantly higher in fish fed FM55 (0.840 (SE 0.031) g) compared with those fed FM63 (0.705 (SE 0.037) g) or FM50 (0.724 (SE 0.037) g). Accounting for W, the HSI was significantly lower for fish fed FM50 (1.07 (SE 0.05)\% W) compared with those fed FM55 (1.27 (SE 0.04)\% W); fish fed FM63 (1.25 (SE $0.06) \% \mathrm{~W}$ ) were not different from either of the other two diets. However, liver protein whether expressed as concentration or total protein was not different among the diets.

\section{Validation of flooding dose}

The time course for the incorporation of $\left[{ }^{3} \mathrm{H}\right]$ phenylalanine showed that the flooding-dose technique is suitable for the study of protein turnover in sea bream (Fig. 1). Incorporation into the liver and white muscle was measured between 28 and $176 \mathrm{~min}$ following injection and increased over the range of incorporation times (ANOVA, $P<0.05$ ). The free phenylalanine concentration in the white muscle free pool was 388 (sE 41) nmol phenylalanine/g wet mass. Using a white muscle free phenylalanine concentration of $150 \mathrm{nmol}$ phenylalanine/g wet mass in uninjected fish, there was more than a 2 -fold increase in free phenylalanine following injection.

There was a significant difference between liver free-pool $\left(S_{\mathrm{a}}\right)$ phenylalanine-specific radioactivity $(\mathrm{dpm} / \mathrm{nmol}$ phenylalanine) at different times $\left(F_{4,7}=5.363, P=0.027\right)$ (Fig. 1(a)). This was due to $S_{\mathrm{a}}$ being significantly higher at $110 \mathrm{~min}$ than at $176 \mathrm{~min}$. The decrease in $S_{\mathrm{a}}$ at $176 \mathrm{~min}$ caused a weak linear relationship between incorporation time and liver free-pool $\left(S_{\mathrm{a}}\right)$ phenylalanine-specific radioactivity described by $S_{\mathrm{a}}=1235-3 \cdot 196 t\left(R^{2} 0.276, \quad F_{1,10}=5 \cdot 187, \quad P=0.046\right)$; there was no relationship when the $176 \mathrm{~min}$ data were excluded. Over the incorporation time, there was a positive linear relationship between time and protein-bound $\left(S_{\mathrm{b}}\right)$ phenylalanine-specific radioactivity $(\mathrm{dpm} / \mathrm{nmol}$ phenylalanine $)$ described by $S_{\mathrm{b}}=0.115 t+0.361 \quad\left(R^{2} 0.900\right.$, $F_{1,10}=99 \cdot 7, P<0.001$ ) (Fig. 1(b)). Thus, the flooding-dose method was valid for incorporation times of between 28 and $110 \mathrm{~min}$ in the liver.

There were no significant differences between white muscle free-pool $\left(S_{\mathrm{a}}\right)$ phenylalanine-specific radioactivity $(\mathrm{dpm} / \mathrm{nmol}$ phenylalanine $)$ at different times $\left(F_{4,7}=0.863, P=0.530\right)$ and white muscle free pools therefore remained flooded for at least $176 \mathrm{~min}$. The free-pool $S_{\mathrm{a}}$ in the white muscle was 936 (sE 91) $\mathrm{dpm} / \mathrm{nmol}$ phenylalanine, $64 \%$ of the injection solution (Fig. 1(c)). Over the time course, there was a linear relationship between time and protein-bound $\left(S_{\mathrm{b}}\right)$ phenylalanine-specific

Table 2. Morphometric data for sea bream fed diets with differing fishmeal content

(Mean values with their standard errors, $n 3$ )

\begin{tabular}{|c|c|c|c|c|c|c|c|c|}
\hline \multirow[t]{2}{*}{ Diet. . . } & \multicolumn{2}{|c|}{ FM63 } & \multicolumn{2}{|c|}{ FM55 } & \multicolumn{2}{|c|}{ FM50 } & \multirow[b]{2}{*}{$F$} & \multirow[b]{2}{*}{$P$} \\
\hline & Mean & SE & Mean & SE & Mean & $\mathrm{SE}$ & & \\
\hline Final weight $(\mathrm{g})$ & $65 \cdot 5$ & $4 \cdot 1$ & $67 \cdot 1$ & 1.9 & $63 \cdot 6$ & $3 \cdot 2$ & 0.306 & 0.747 \\
\hline Weight gain $(\mathrm{g})$ & $29 \cdot 6$ & 3.5 & 31.5 & $1 \cdot 1$ & $29 \cdot 4$ & $2 \cdot 8$ & 0.192 & 0.831 \\
\hline $\mathrm{SGR}^{\star}(\% / \mathrm{d})$ & 1.71 & 0.13 & 1.81 & 0.02 & 1.77 & 0.11 & 0.246 & 0.789 \\
\hline Feed intake (g) & $38 \cdot 1$ & 1.0 & 39.8 & 0.8 & 39.3 & 1.5 & 0.580 & 0.589 \\
\hline FER $\dagger(\mathrm{g} / \mathrm{g})$ & 1.32 & 0.12 & $1 \cdot 27$ & 0.02 & 1.35 & 0.09 & 0.265 & 0.776 \\
\hline
\end{tabular}

FM63, 63\% fishmeal; FM55, 55\% fishmeal with approximately $16 \%$ fishmeal protein replaced by soyabean protein; FM50, $50 \%$ fishmeal with approximately $27 \%$ fishmeal protein replaced by soyabean and maize gluten protein; SGR, specific growth rate; FER, feed efficiency ratio.

* $\mathrm{SGR}=100 \times((\mathrm{Ln}$ (final weight/initial weight) $) / 35 \mathrm{~d})$.

$\dagger \mathrm{FER}=$ feed intake $(\mathrm{g}) /$ weight gain $(\mathrm{g})$. 

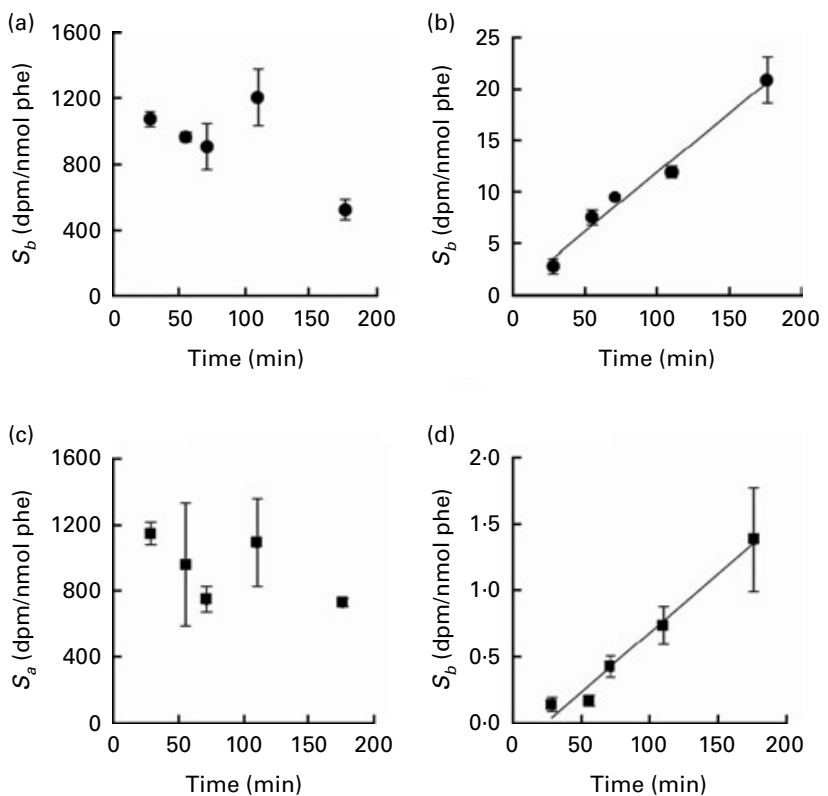

Fig. 1. Time course for phenylalanine-specific radioactivity $(\mathrm{dpm} / \mathrm{nmol}$ phenylalanine (phe)) in (a) liver free pool (significant differences between 28 and $176 \mathrm{~min}: F_{4,7}=5.36, \quad P=0.027$ ); (b) liver protein, as described by $S_{\mathrm{b}}=0.115 \times(0.012) t+0.361 \times(1.271)\left(R^{2} 0.90, F_{1,10}=99.7, P<0.001\right) ;(\mathrm{c})$ white muscle free pool (no differences between times: $F_{4,7}=0.86, P=0.53$ ); (d) white muscle protein, as described by $S_{\mathrm{b}}=0.009 \times(0.002) t-0.201 \times(0.202)$ $\left(R^{2} 0.67, F_{1,10}=23.34, P<0.001\right)$. Values are means, with their standard errors represented by vertical bars.

radioactivity (dpm/nmol phenylalanine) described by $S_{\mathrm{b}}=0.009 t-0.201\left(R^{2} 0 \cdot 67, F_{1,10}=23.3, P<0 \cdot 001\right)($ Fig. $1(\mathrm{~d}))$. Thus, the flooding-dose method was valid for incorporation times of between 28 and $176 \mathrm{~min}$ in the white muscle.

\section{Postprandial protein metabolism}

Detailed examination of postprandial protein metabolism was made between diets FM63 and FM50 by measuring protein synthesis and capacity for protein synthesis before and at 4, 8, 12, 24 and $48 \mathrm{~h}$ after feeding one meal. Liver protein synthesis was not different $\left(F_{1,36}=0 \cdot 146, P=0.704\right)$ between the two diets, whereas there were significant differences $\left(F_{5,36}=8 \cdot 245\right.$, $P<0 \cdot 001)$ due to time. Liver rates of protein synthesis were significantly lower before feeding and at 24 and $48 \mathrm{~h}$ after feeding than at 4 and $8 \mathrm{~h}$ after feeding (Fig. 2(a)). White muscle protein synthesis had similar responses; it was not affected by diet $\left(F_{1,36}=0.314\right.$, $P=0.579)$ but only by time $\left(F_{5,36}=7.000, P<0.001\right)$; rates were significantly lower before and at 24 and $48 \mathrm{~h}$ after feeding than at 4 and $8 \mathrm{~h}$ after feeding (Fig. 2(b)). Thus, the peak rates of protein synthesis were similar in the two tissues and across the two diets. In contrast, the capacity for protein synthesis was not affected by diet or by time in either tissue; the overall mean values were 81.02 (SE 1.682) and 4.147 (SE 0.147) $\mathrm{mg} \mathrm{RNA} / \mathrm{g}$ protein for the liver and white muscle, respectively.

\section{Diet comparison using protein metabolism}

Protein metabolism of fish fed FM55 was compared with diets FM63 and FM50 at selected times (0, 4, 24 and 48h) to
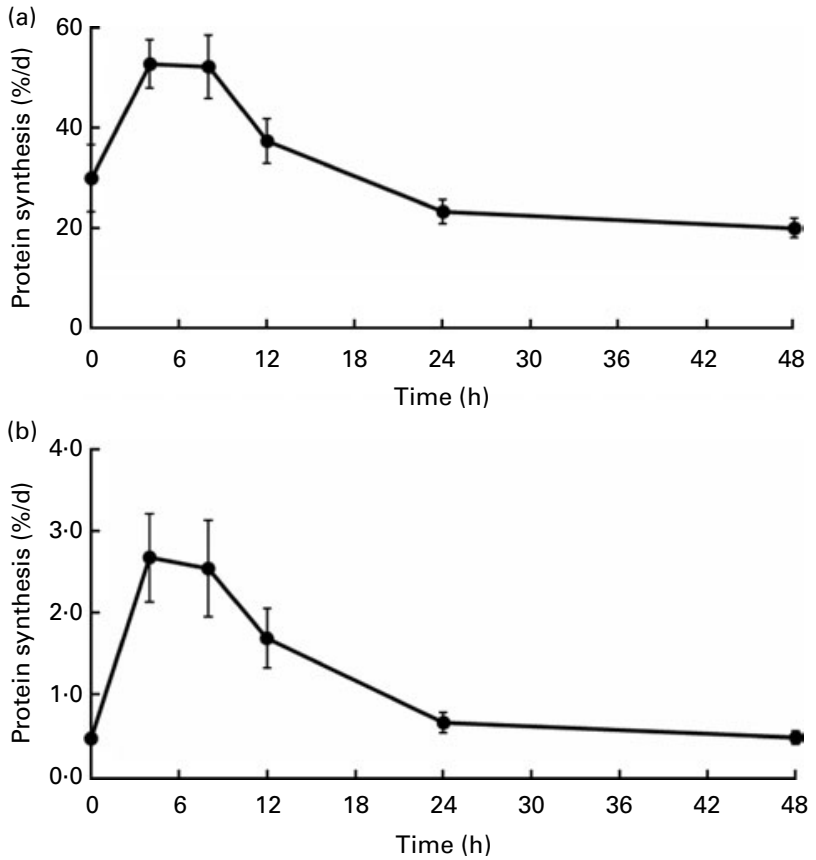

Fig. 2. Protein synthesis (\%/d) in (a) liver and (b) white muscle of sea bream before feeding and at different times after feeding. Values are means, with their standard errors represented by vertical bars $(n 8)$.

examine whether there were any differences due to diet or time after feeding. Diet did not influence protein synthesis or the capacity for protein synthesis in either tissue. However, time after feeding had a significant effect on protein synthesis. At $4 \mathrm{~h}$, protein synthesis was higher than at the other three times for all diets and for both liver (Table 3) and white muscle (Table 4). Absolute liver protein synthesis was significantly lower in fish fed FM55 (0.022 (SE 0.005) g protein) than in those fed FM50 (0.027 (SE 0.003) g protein) or FM63 (0.026 (SE 0.002) g protein). Neither time nor diet influenced the capacity for protein synthesis; the overall mean values were 81.021 (SE 1.682) $\mathrm{mg} \mathrm{RNA/g} \mathrm{protein} \mathrm{and} 4.066$ (SE 0.943) mg $\mathrm{RNA} / \mathrm{g}$ protein for the liver and white muscle, respectively.

There was individual variation in the indices of protein metabolism and a positive correlation between the liver and white muscle fractional rates of protein synthesis $(r 0.477$; $P<0.01 ; n$ 60) and the tissues' RNA activity ( $r \quad 0.497$; $P<0.01 ; n$ 60). There was no correlation between the tissues capacity for protein synthesis. Thus, individual variation in protein metabolism was via changes in RNA activity rather than RNA content.

\section{Discussion}

The main result from the present study was the similarity in measures of protein metabolism among fish fed three isonitrogenous diets with different levels of fishmeal and other protein sources. The measurement of protein metabolism was comprehensive and focused on the two key tissues, the liver and white muscle, and at different times after feeding. Postprandial protein synthesis peaked at $4 \mathrm{~h}$ in both tissues and remained elevated for at least $4 \mathrm{~h}$ before returning to pre-feeding 
Table 3. Liver fractional rates of protein synthesis $\left(k_{\mathrm{s}}: \% / \mathrm{d}\right)$ for sea bream fed diets with differing fishmeal content before feeding $(0 \mathrm{~h})$ and at different times after feeding

(Mean values with their standard errors, $n 4$ )

\begin{tabular}{|c|c|c|c|c|c|c|c|c|}
\hline \multirow{2}{*}{$\begin{array}{l}\text { Time after feeding }(\mathrm{h}) \ldots \\
\text { Diets }\end{array}$} & \multicolumn{2}{|c|}{0} & \multicolumn{2}{|c|}{4} & \multicolumn{2}{|c|}{24} & \multicolumn{2}{|c|}{48} \\
\hline & Mean & SE & Mean & SE & Mean & SE & Mean & SE \\
\hline FM63 & $22 \cdot 30$ & $2 \cdot 23$ & 53.41 & $8 \cdot 11$ & 27.02 & 3.44 & 21.83 & 3.09 \\
\hline FM55 & $19 \cdot 16$ & 1.72 & 65.35 & 0.57 & 21.02 & 1.62 & 17.97 & 4.09 \\
\hline FM50 & $35 \cdot 70$ & $12 \cdot 31$ & $52 \cdot 15$ & $6 \cdot 50$ & 19.56 & $2 \cdot 38$ & 18.02 & 2.48 \\
\hline Combined by diet & $25 \cdot 72^{\mathrm{a}}$ & 3.27 & $56 \cdot 97^{b}$ & 3.59 & $22 \cdot 54^{a}$ & $3 \cdot 11$ & $19 \cdot 27^{\mathrm{a}}$ & 3.28 \\
\hline Statistics & Time & Diet & Interaction & & & & & \\
\hline$F$ & 24.80 & 0.007 & 1.42 & & & & & \\
\hline$P$ & 0.000 & 0.993 & 0.237 & & & & & \\
\hline
\end{tabular}

FM63, 63\% fishmeal; FM55, 55\% fishmeal with approximately $16 \%$ fishmeal protein replaced by soyabean protein; FM50, $50 \%$ fishmeal with approximately $27 \%$ fishmeal protein replaced by soyabean and maize gluten protein.

a,b Mean values with the same superscript letters across time when combined by diet were not significantly different following two-way ANOVA and multiple comparison by Tukey's honestly significant difference.

levels after $24 \mathrm{~h}$. The measures of protein metabolism were mainly made within a $24 \mathrm{~h}$ daily cycle and the absence of a diet effect was reflected by the similarity in long-term measures of growth performance. Interestingly, diet had a subtle influence on the liver so that the overall effect was fish fed FM55 synthesised less liver protein despite similar fractional rates of protein synthesis. Capacity for protein synthesis did not change following feeding and showed that the changes in protein synthesis were primarily due to the changes in RNA activity in both tissues. Thus, the pattern of postprandial protein synthesis in sea bream was broadly similar to other warm-water fish species ${ }^{(18,34)}$ and to when nutritionally similar diets were fed to previously well-fed fish ${ }^{(15)}$.

\section{Postprandial protein synthesis}

Postprandial metabolism, often termed specific dynamic action or heat increment, reflects the many physiological changes stimulated by a meal ${ }^{(35)}$. As with other animals, protein synthesis accounts for a large part of postprandial energy expenditure in fish and emphasises the importance of understanding postprandial protein synthesis ${ }^{(17,18,36)}$. To our knowledge, the in vivo effect of diet on postprandial protein synthesis in fish has been measured by only Katersky \& Carter ${ }^{(15)}$. Sea bream in the present study increased white muscle rates by over five times during the peak at 4 and $8 \mathrm{~h}$ after feeding; protein synthesis peaked in the liver at the same time and increased by about 1.7 times. In warm-water fish, there appears to be closer alignment between peak activity in the liver and white muscle ${ }^{(34)}$, whereas the liver peak rate precedes the white muscle peak in colder-water species $^{(11)}$. The relative increase is typically larger in the liver than in the white muscle ${ }^{(11)}$. This has been explained by the liver's primary role in primary processing of ingested nutrients and exportation of amino acids and synthesised proteins from the liver to peripheral tissues ${ }^{(14,18,37)}$. In contrast, stimulation of peak protein synthesis in sea bream white muscle was higher than for the liver, whereas the relative increase was similar between the two tissues for barramundi ${ }^{(34)}$. The explanation may be due to a complex mix of differences between experiments that include fish species, age and size as well as to differences in dietary and environmental factors.

\section{Dietary protein and protein synthesis}

In the present study, sea bream were fed three nutritionally balanced diets that provided optimum protein within the range of $40-48 \%^{(38-40)}$ at an optimum protein:energy ratio of about $28.5 \mathrm{~g}$ dietary crude protein/dietary energy ${ }^{(41)}$. They

Table 4. White muscle fractional rates of protein synthesis $\left(k_{\mathrm{s}}: \% / d\right)$ for sea bream fed diets with differing fishmeal content before feeding and at different times after feeding

(Mean values with their standard errors, $n 4$ )

\begin{tabular}{|c|c|c|c|c|c|c|c|c|}
\hline \multirow{2}{*}{$\begin{array}{l}\text { Time after feeding }(\mathrm{h}) \ldots \\
\text { Diets }\end{array}$} & \multicolumn{2}{|c|}{0} & \multicolumn{2}{|c|}{4} & \multicolumn{2}{|c|}{24} & \multicolumn{2}{|c|}{48} \\
\hline & Mean & SE & Mean & $\mathrm{SE}$ & Mean & SE & Mean & $\mathrm{SE}$ \\
\hline FM63 & 0.531 & 0.035 & $2 \cdot 913$ & 1.039 & 0.796 & 0.196 & 0.534 & 0.152 \\
\hline FM55 & 0.461 & 0.068 & 2.971 & $1 \cdot 111$ & 0.830 & 0.191 & 0.636 & 0.180 \\
\hline FM50 & 0.406 & 0.045 & $2 \cdot 421$ & 0.497 & 0.515 & 0.152 & 0.409 & 0.059 \\
\hline Combined by diet & $0.466^{\mathrm{a}}$ & 0.031 & $2 \cdot 750^{\mathrm{b}}$ & 0.467 & $0 \cdot 714^{\mathrm{a}}$ & 0.104 & $0.527^{a}$ & 0.078 \\
\hline Statistics & Time & Diet & Interaction & & & & & \\
\hline$F$ & $18 \cdot 71$ & 0.538 & 0.069 & & & & & \\
\hline$P$ & 0.000 & 0.589 & 0.999 & & & & & \\
\hline
\end{tabular}

FM63, 63\% fishmeal; FM55, 55\% fishmeal with approximately $16 \%$ fishmeal protein replaced by soyabean protein; FM50, 50\% fishmeal with approximately $27 \%$ fishmeal protein replaced by soyabean and maize gluten protein.

a,b Mean values with the same superscript letters across time when combined by diet were not significantly different following two-way ANOVA and multiple comparison by Tukey's honestly significant difference. 
were formulated to replace some fishmeal with alternative protein sources, and sea bream showed very similar growth performance that was matched by indices of protein metabolism. The similarity in responses was therefore not unexpected but the present study is the first published study on fish to directly compare dietary effects on postprandial protein synthesis at multiple time points following feeding. In the few studies on fish that compared diets, protein synthesis was usually measured at a single time point after feeding ${ }^{(10,26)}$ that was often not specified ${ }^{(8,42,43)}$. To account for specific dynamic action, protein synthesis was measured at peak $(4 \mathrm{~h})$ and baseline $(24 \mathrm{~h})$ rates in barramundi ${ }^{(15)}$.

Differences in dietary amino acid balance of alternative protein sources partly explain decreased long-term growth performance, and these differences are also highlighted by differences in protein turnover ${ }^{(9,10)}$. At a physiological level and as a method, protein synthesis effectively integrates amino acid supply to provide an assessment of protein quality $^{(11,44)}$. Diets that provide a poor amino acid balance tend to stimulate liver protein synthesis ${ }^{(8)}$ and depress white muscle protein synthesis ${ }^{(7)}$. At the whole animal level, diets with poorer amino acid balance stimulated protein synthesis ${ }^{(9,10)}$; this effect was because protein synthesis was measured at $3 \mathrm{~h}$ after feeding when, presumably, peak rates of liver protein synthesis accounted for a large proportion of total protein synthesised. At peak rates, liver protein synthesis can often account for most of whole-fish protein synthesis ${ }^{(34)}$. In addition to time after feeding, response also depends on the extent of amino acid deficiency in a way that reflects the interaction between dietary protein content and quality in relation to requirements ${ }^{(11)}$. At marginal amino acid deficiency, on a marginally deficient diet or after a short length of time on a deficient diet, fish compensate and protein metabolism is stimulated in the liver in order to maintain muscle protein synthesis and growth ${ }^{(14)}$. Where the deficiency is more extreme, due to a more deficient diet or after a longer time, protein metabolism will down-regulate so that liver rates are similar or depressed and white muscle rates are depressed ${ }^{(7,42)}$. This suggests that measuring protein synthesis in the liver after a short period of time will highlight up-regulation due to amino acid deficiency, whereas measuring white muscle and whole-animal protein synthesis at the end of a growth experiment will explain the cause of differences in growth due to differences in protein turnover.

The present study suggested that there were some dietary differences in the liver. The liver size of fish fed FM55 was larger but liver protein concentration was lower, which meant that the total liver protein was not statistically different among the three diets. In contrast, total liver protein synthesis was significantly lower for FM55 despite there being no difference among the fractional rates of liver protein synthesis. The fish liver is sensitive to dietary differences and has a high capacity to compensate for some nutritional imbalances in order to optimise white muscle protein turnover and prioritise protein growth $^{(14,45)}$. In the present study, fish fed FM55 synthesised $84 \%$ of the total protein compared with the other diets. Similarly, brown trout (Salmo trutta) fed a control diet synthesised $88 \%$ of the total liver protein compared with those fed a slightly less adequate diet with higher carbohydrate and the need for greater export of liver proteins for muscle growth ${ }^{(45)}$. Further research would be required to demonstrate whether FM55 was the better diet of the three tested.

An aim of much fish nutrition research is to replace fishmeal protein with alternative protein sources and, as in the present study, this generally requires the use of more than one alternative source. The measurement of protein synthesis can inform this process by highlighting differences between diets; as discussed above, the differences may be subtle and the measurement of protein synthesis in different tissues and at different times following feeding has the potential to highlight these. Lupin provides an excellent fishmeal replacement and $45 \%$ replacement of fishmeal with lupin meal had no effect on white muscle protein synthesis at 4 or $24 \mathrm{~h}$ following feeding ${ }^{(15)}$. Rainbow trout fed two different diets, both with mixed protein sources, had similar growth after 12 weeks, but there were differences in protein synthesis ${ }^{(16)}$ which might suggest that a significant growth difference would become apparent after a longer time or at the same ration. The diets used for juvenile sea bream in the present study were formulated to reflect optimum protein supply and the similarity in growth and protein metabolism supports the use of alternative protein sources to replace part of the fishmeal.

\section{Acknowledgements}

The authors wish to express their thanks to G. Varvatsoulis and the Zoonomi Aquafeed Company for their help with feeds and to Panagiotis Ex and Antigoni Vasilaki for assistance with fish husbandry. Funding from the European Commission and the Hellenic Ministry of Rural Development and Food is gratefully acknowledged. The assistance of a member of the Editorial Board is gratefully acknowledged. All authors contributed to all parts of the research. The authors declare that there are no conflicts of interest.

\section{References}

1. Miller MR, Nichols PD \& Carter CG (2008) n-3 Oil sources for use in aquaculture - alternatives to the unsustainable harvest of wild fish. Nutr Res Rev 21, 85-96.

2. Naylor RL, Hardy RW, Bureau DP, et al. (2009) Feeding aquaculture in an era of finite resources. Proc Nat Acad Sci U S A 106, 15103-15110.

3. Bostock J, McAndrew B, Richards R, et al. (2010) Aquaculture: global status and trends. Phil Trans Roy Soc B 365, 2897-2912.

4. Hardy RW (2010) Utilization of plant proteins in fish diets: effects of global demand and supplies of fishmeal. Aquacult Res 41, 770-776.

5. Mente E, Karalazos V, Karapanagiotidis IT, et al. (2011) Nutrition in organic aquaculture: an inquiry and a discourse. Aquacult Nutr 17, E798-E817.

6. Vilhelmsson OT, Martin SA, Medale F, et al. (2004) Dietary plant-protein substitution affects hepatic metabolism in rainbow trout (Oncorbynchus mykiss). Br J Nutr 92, 71-80.

7. De la Higuera M, Akharbach H, Hidalgo MC, et al. (1999) Liver and white muscle protein turnover rates in the 
European eel (Anguilla anguilla): effects of dietary protein quality. Aquaculture 179, 203-216.

8. De la Higuera M, Garzon A, Hidalgo MC, et al. (1998) Influence of temperature and dietary-protein supplementation either with free or coated lysine on the fractional protein-turnover rates in the white muscle of carp. Fish Physiol Biochem 18, 85-95.

9. Langer H \& Guillaume J (1994) Effect of feeding pattern and dietary protein source on protein synthesis in European sea bass (Dicentrarchus labrax). Comp Biochem Physiol $A$ 108A, 461-466.

10. Langer H, Guillaume J, Metailler R, et al. (1993) Augmentation of protein synthesis and degradation by poor dietary amino acid balance on European sea bass (Dicentrarchus labrax). J Nutr 123, 1754-1761.

11. Carter CG \& Houlihan DF (2001) Protein synthesis. In Nitrogen Excretion, Fish Physiology, vol. 20, pp. 31-75 [PA Wright and PM Anderson, editors]. San Diego: Academic Press.

12. Mente E, Coutteau P, Houlihan D, et al. (2002) Protein turnover, amino acid profile and amino acid flux in juvenile shrimp Litopenaeus vannamei: effects of dietary protein source. J Exp Biol 205, 3107-3122.

13. Panserat S \& Kaushik SJ (2010) Regulation of gene expression by nutritional factors in fish. Aquacult Res $\mathbf{4 1}$, 751-762.

14. Peragon J, Barroso JB, Garcia-Salguero L, et al. (2000) Dietary alterations in protein, carbohydrates and fat increase liver protein-turnover rate and decrease overall growth rate in the rainbow trout (Oncorbynchus mykiss). Mol Cell Biochem 209, 97-104.

15. Katersky RS \& Carter CG (2009) Growth and protein synthesis of barramundi, Lates calcarifer, fed lupin as a partial protein replacement. Comp Biochem Physiol A 152, 513-517.

16. Martin SA, Vilhelmsson O, Medale F, et al. (2003) Proteomic sensitivity to dietary manipulations in rainbow trout. Biochim Biophys Acta 1651, 17-29.

17. Lyndon AR, Houlihan DF \& Hall SJ (1992) The effect of short-term fasting and a single meal on protein synthesis and oxygen consumption in cod, Gadus morbua. J Comp Physiol B162, 209-215.

18. McCarthy ID \& Fuiman LA (2011) Post-prandial changes in protein synthesis in red drum (Sciaenops ocellatus) larvae. $J$ Exp Biol 214, 1821-1828.

19. Millward DJ (1989) The nutritional regulation of muscle growth and protein turnover. Aquaculture 79, 1-28.

20. Gomez-Requeni $\mathrm{P}$, Mingarro M, Calduch-Giner JA, et al. (2004) Protein growth performance, amino acid utilisation and somatotropic axis responsiveness to fish meal replacement by plant protein sources in gilthead sea bream (Sparus aurata). Aquaculture 232, 493-510.

21. Santigosa E, Garcia-Meilan I, Valentin JM, et al. (2008) Modifications of intestinal nutrient absorption in response to dietary fish meal replacement by plant protein sources in sea bream (Sparus aurata) and rainbow trout (Onchorynchus mykiss). Aquaculture 317, 146-154.

22. Robaina L, Izquirdo MS, Moyano FJ, et al. (1995) Soybean and lupin seed meals as protein sources in diets for gilthead bream (Sparus aurata) - nutritional and histological implications. Aquaculture 130, 219-233.

23. Nengas I, Alexis MN, Davies SJ, et al. (1995) Investigation to determine digestibility coefficients of various raw materials in diets for gilthead sea bream, Sparus aurata L. Aquacult Res 26, 185-194.
24. Nengas I, Alexis MN \& Davis SJ (1996) Partial substitution of fishmeal with soybean meal products and derivatives in diets for the gilthead sea bream Sparus aurata (L.). Aquacult Res 27, 147-156.

25. Garlick PJ, McNurlan MA \& Preedy VR (1980) A rapid and convenient technique for measuring the rate of protein synthesis in tissues by injection of ${ }^{3} \mathrm{H}$ phenylalanine. Biochem J 192, 719-723.

26. Carter CG, Houlihan DF, Brechin J, et al. (1993) The relationships between protein intake and protein accretion, synthesis and retention efficiency for individual grass carp, Ctenopharyngodon idella (Valenciennes). Can J Zool $\mathbf{7 1}$, 392-400.

27. Fraser KPP \& Rogers AD (2007) Protein metabolism in marine animals: the underlying mechanism of growth. $A d v$ Mar Biol 52, 267-362.

28. Houlihan DF, Carter CG \& McCarthy ID (1995) Protein turnover in animals. In Nitrogen and Excretion, pp. 1-29 [PJ Wright and PA Walsh, editors]. Boca Raton, FL: CRC Press.

29. McNurlan MA, Tomkins AM \& Garlick PJ (1979) The effect of starvation on the rate of protein synthesis in rat liver and small intestine. Biochem J 178, 373-379.

30. Garlick PJ, Fern M \& Preedy VR (1983) The effect of insulin infusion and food intake on muscle protein synthesis in postabsorptive rats. Biochem J 210, 669-676.

31. Lowry HO, Rosebrough NJ, Farr AL, et al. (1951) Protein measurement with Folin phenol reagent. J Biol Chem 193, 265-275.

32. Ashford AJ \& Pain VM (1986) Effect of diabetes on the rates of protein synthesis and degradation of ribosomes in rat muscle and liver in vivo. J Biol Chem 261, 4059-4065.

33. Sugden PH \& Fuller SJ (1991) Regulation of protein turnover in skeletal and cardiac muscle. Biochem J 273, 21-37.

34. Katersky RS \& Carter CG (2010) The effect of temperature on post-prandial protein synthesis in juvenile barramundi, Lates calcarifer. Comp Biochem Physiol A 156, 529-536.

35. McCue MD (2006) Specific dynamic action: a century of investigation. Comp Biochem Physiol A 144, 381-394.

36. Brown CR \& Cameron JN (1991) The relationship between specific dynamic action (SDA) and protein synthesis rate in channel catfish. Physiol Zool 64, 298-309.

37. Carter CG, He ZY, Houlihan DF, et al. (1995) Effect of feeding on tissue free amino acid concentrations in rainbow trout (Oncorbynchus mykiss Walbaum). Fish Physiol Biochem 14, 153-164.

38. Company R, Calduch-Giner JA, Kaushik S, et al. (1999) Growth performance and adiposity in gilthead seabream (Sparus aurata): risks and benefits of high energy diets. Aquaculture 171, 279-292.

39. Gomez-Requeni P, Mingarro M, Kirchner S, et al. (2003) Effects of dietary amino acid profile on growth performance, key metabolic enzymes and somatotropic axis responsiveness of gilthead sea bream (Sparus aurata). Aquaculture 220, $749-767$.

40. Vergara JM, Robaina L, Izquierdo M, et al. (1996) Protein sparing effect of lipids in diets for fingerlings of gilthead sea bream. Fish Sci 62, 624-628.

41. Lupatsch I, Kissil GW, Sklan D, et al. (2001) Effects of varying dietary protein and energy supply on growth, body composition and protein utilization in gilthead seabream (Sparus aurata L.). Aquacult Nutr 7, 71-80.

42. Peragon J, Barroso JB, Garcia-Salguero L, et al. (1994) Dietary protein effects on growth and fractional protein synthesis and degradation rates in liver and white muscle of rainbow trout (Oncorbynchus mykiss). Aquaculture 124, 35-46. 
43. Sveier H, Raae AJ \& Lied E (2000) Growth and protein turnover in Atlantic salmon (Salmo salar L.); the effect of dietary protein level and protein particle size. Aquaculture 185, 101-120.

44. Young VR, Yu Y-M \& Krempf M (1991) Protein and amino acid turnover using the stable isotopes ${ }^{15} \mathrm{~N},{ }^{13} \mathrm{C}$, and ${ }^{2} \mathrm{H}$ as probes. In New Techniques in Nutritional Research, pp. 17-72 [RG Whithead and A Prentice, editors]. San Diego: Academic Press.
45. Viaplana-Marin I, Fernandez-Borras J \& Blasco J (2006) Effects of the protein/carbohydrate ratio of extruded diets on protein synthesis, protein growth and body composition in juvenile brown trout (Salmo trutta). Aquacult Int 14, $337-353$.

46. Brafield AE (1985) Laboratory studies of energy budgets. In Fish Energetics New Perspectives, pp. 257-281 [P Tytler and P Calow, editors]. London/Sydney: Croom Helm. 